University of Nebraska - Lincoln

DigitalCommons@University of Nebraska - Lincoln

USDA Wildlife Services - Staff Publications

U.S. Department of Agriculture: Animal and Plant Health Inspection Service

2014

\title{
Mineral licks: motivational factors for visitation and accompanying disease risk at communal use sites of elk and deer
}

\author{
Michael J. Lavelle \\ USDA/APHIS/WS National Wildlife Research Center, michael.j.lavelle@aphis.usda.gov \\ Gregory E. Phillips \\ United States Department of Agriculture, Animal and Plant Health Inspection Service, Wildlife Services, \\ National Wildlife Research Center, Fort Collins, CO \\ Justin W. Fischer \\ USDA/APHIS/WS National Wildlife Research Center, Justin.w.fischer@aphis.usda.gov \\ Patrick W. Burke \\ Wyoming Game and Fish Department, Green River, WY \\ Nathan W. Seward \\ Colorado Division of Wildlife, Gunnison, CO
}

See next page for additional authors

Follow this and additional works at: https://digitalcommons.unl.edu/icwdm_usdanwrc

Part of the Life Sciences Commons

Lavelle, Michael J.; Phillips, Gregory E.; Fischer, Justin W.; Burke, Patrick W.; Seward, Nathan W.; Stahl, Randal S.; Nichols, Tracy A.; Wunder, Bruce A.; and VerCauteren, Kurt C., "Mineral licks: motivational factors for visitation and accompanying disease risk at communal use sites of elk and deer" (2014). USDA Wildlife Services - Staff Publications. 1704.

https://digitalcommons.unl.edu/icwdm_usdanwrc/1704

This Article is brought to you for free and open access by the U.S. Department of Agriculture: Animal and Plant Health Inspection Service at DigitalCommons@University of Nebraska - Lincoln. It has been accepted for inclusion in USDA Wildlife Services - Staff Publications by an authorized administrator of DigitalCommons@University of Nebraska - Lincoln. 


\section{Authors}

Michael J. Lavelle, Gregory E. Phillips, Justin W. Fischer, Patrick W. Burke, Nathan W. Seward, Randal S. Stahl, Tracy A. Nichols, Bruce A. Wunder, and Kurt C. VerCauteren 


\title{
Mineral licks: motivational factors for visitation and accompanying disease risk at communal use sites of elk and deer
}

\author{
Michael J. Lavelle • Gregory E. Phillips • Justin W. Fischer • Patrick W. Burke • \\ Nathan W. Seward - Randal S. Stahl - Tracy A. Nichols • Bruce A. Wunder • \\ Kurt C. VerCauteren
}

Received: 14 May 2012/ Accepted: 15 March 2014/Published online: 8 April 2014

(C) Springer Science+Business Media Dordrecht 2014 (outside the USA) 2014

\begin{abstract}
Free-ranging cervids acquire most of their essential minerals through forage consumption, though occasionally seek other sources to account for seasonal mineral deficiencies. Mineral sources occur as natural geological deposits (i.e., licks) or as anthropogenic mineral supplements. In both scenarios, these sources commonly serve as focal sites for visitation. We monitored 11 licks in Rocky Mountain National Park, north-central Colorado, using trail cameras to quantify daily visitation indices (DVI) and soil consumption indices (SCI) for Rocky Mountain elk (Cervus elaphus) and mule deer (Odocoileus hemionus) during summer 2006 and documented elk, mule deer, and moose (Alces alces) visiting licks.
\end{abstract}

M. J. Lavelle $(\bowtie) \cdot$ G. E. Phillips · J. W. Fischer ·

R. S. Stahl - T. A. Nichols - K. C. VerCauteren

United States Department of Agriculture, Animal and

Plant Health Inspection Service, Wildlife Services,

National Wildlife Research Center, 4101 LaPorte Avenue,

Fort Collins, CO 80521-2154, USA

e-mail: michael.j.lavelle@aphis.usda.gov

P. W. Burke

Wyoming Game and Fish Department, Green River,

WY 82935-0663, USA

N. W. Seward

Colorado Division of Wildlife, Gunnison, CO 81230, USA

B. A. Wunder

Professor Emeritus, Department of Biology, Colorado

State University, Fort Collins, CO 80523-1878, USA
Additionally, soil samples were collected, and mineral concentrations were compared to discern levels that explain rates of visitation. Relationships between response variables; DVI and SCI, and explanatory variables; elevation class, moisture class, period of study, and concentrations of minerals were examined. We found that DVI and SCI were greatest at two wet, low-elevation licks exhibiting relatively high concentrations of manganese and sodium. Because cervids are known to seek $\mathrm{Na}$ from soils, we suggest our observed association of Mn with DVI and SCI was a likely consequence of deer and elk seeking supplemental dietary Na. Additionally, highly utilized licks such as these provide an area of concentrated cervid occupation and interaction, thus increasing risk for environmental transmission of infectious pathogens such as chronic wasting disease, which has been shown to be shed in the saliva, urine, and feces of infected cervids.

Keywords Cervus elaphus - Chronic wasting disease $\cdot$ Elk $\cdot$ Geophagy $\cdot$ Mineral lick $\cdot$ Mule deer $\cdot$ Odocoileus hemionus

\section{Introduction}

Cervids and other ungulates satisfy mineral requirements by complementing consumption of forages with intake of mineral-rich soil and water (Jones and Hanson 1985; Jones and Weeks 1985), or 
anthropogenic supplementation (Schultz and Johnson 1992). Geophagy, consumption of soil, is a behavior common among ruminants and appears to be a strategy to address mineral deficiencies (Jones and Hanson 1985; Stephenson et al. 2011) and possibly even selfmedicate (National Research Council 2007; Stephenson et al. 2011). Anthropogenically sourced licks are provided in attempts to increase antler size (Campbell and Hewitt 2004), supplement animal diets, and manipulate animal movement (Case 1938). Natural licks typically fall into two categories: wet licks, which are often associated with mineral-rich springs or seeps, and dry licks, which are concentrations of soluble minerals exposed by animals, erosion, evaporation, or other pedogenic processes (Ayotte et al. 2008).

To better understand the selection and visitation of elk (Cervus elaphus) and mule deer (Odocoileus hemionus) at naturally occurring licks in Rocky Mountain National Park (RMNP), we installed digital trail cameras at suspected licks and collected soil samples to establish nutritional mineral concentrations. We sought to explore relationships between sitespecific visitation, soil consumption indices, as well as characteristics of individual licks. We hypothesized that visitation and soil consumption indices would positively correlate with increased concentrations of macronutrients known to be important for ruminant nutrition that are potentially detectable by animals. For example, animals can innately detect (i.e., taste) several macronutrients, particularly sodium $(\mathrm{Na}$; Schulkin 2001), and to some extent calcium (Ca; Tordoff 2001), magnesium (Mg; McCaughey and Tordoff 2002), and phosphorus ( $\mathrm{P}$; innate appetite restricted primarily to consumption of bones; Denton et al. 1986). Therefore, cervids may have mechanisms to select for these minerals in response to physiological deficiencies, and concentrations of these minerals may act as attractants to licks. Beyond these four macronutrients, we explored for correlations between cervid presence and concentrations of additional macro- and micronutrients, as well as potentially toxic minerals. Animals may also learn to consume required minerals, without directly "tasting" them, by associating positive post-ingestive physiological feedback with visual, olfactory, and gustatory cues from ingested materials (Provenza and Villalba 2006). Thus, additional macro- and micronutrients may influence use of licks.

\section{Materials and methods}

We conducted our study within RMNP in north-central Colorado, including the Poudre River-Chapin Creek valley (south of Hague Creek; $40^{\circ} 28^{\prime} 6^{\prime \prime} \mathrm{N}$, $105^{\circ} 43^{\prime} 57^{\prime \prime} \mathrm{W}$; Fig. 1). Our study area encompassed nearly $23 \mathrm{~km}^{2}$ consisting of wet meadows, coniferous forest, and alpine tundra ranging in elevation from 3,018 to 3,463 m (described by Larkins 1997). Elk, mule deer, and moose (Alces alces) were routinely observed in the study area during late spring, summer, and early fall, though they migrated to lower elevations once snow began to accumulate at higher elevations, in agreement with a previous study by Larkins (1997).

The geographic region encompassing our study area had historical significance in the origin and discovery of chronic wasting disease (CWD), a fatal transmissible spongiform encephalopathy that affects North American cervids such as elk, deer, and moose, as the first case in free-ranging elk was identified in RMNP in 1981 (Spraker et al. 1997). Prevalence rates for elk and deer in Colorado Division of Wildlife's Data Analysis Units E-9 and D-10, which encompassed the study area, were 3 and $14 \%$, respectively, in 2010 (Colorado Division of Wildlife 2010a, b).

We used ArcGIS desktop software (Environmental Systems Research Institute, Redlands, CA, USA) and aerial photography to identify potential licks based on characteristics such as lack of vegetation and size (Fischer and Lavelle 2007) and selected 11 sampling sites with high subjective probability of being used as licks (i.e., depressions $\geq 2 \mathrm{~m}$ in diameter, devoid of vegetation, with evidence of concentrated cervid activity) from on-the-ground observations. We classified licks as wet or dry (Ayotte et al. 2008) and high or low elevation. Wet licks were characterized by saturated soils with running or standing water throughout the season of availability (i.e., snow free). Dry licks were located on slopes and were only temporarily wet following precipitation. High-elevation licks were located in subalpine and alpine habitat (range 3,400-3,600 $\mathrm{m}$ ) and low-elevation licks in riparian meadows (range 3,000-3,125 m).

Licks were monitored using infrared-illuminated digital cameras (Reconyx ${ }^{\mathrm{TM}}$ Silent Image, La Crosse, WI, USA). One camera/lick was installed approximately $20 \mathrm{~m}$ from lick center and $0.5 \mathrm{~m}$ above ground on steel posts. Cameras were programmed to collect 


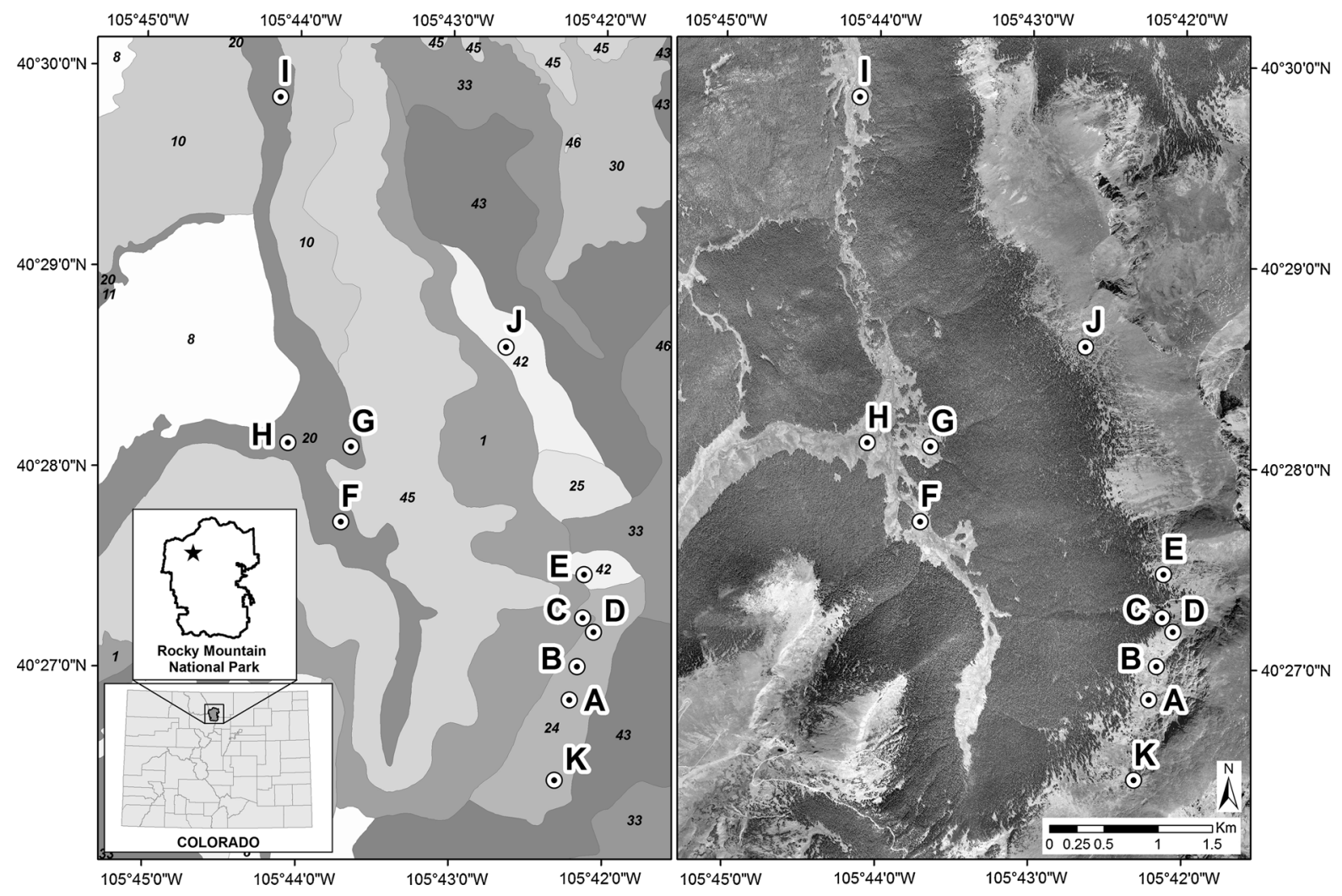

Fig. 1 Maps of study site, with soil series map [relevant soil types referring to numeric identification within soil series boundaries within map on left: 1 Archrock-Fallriver association, 15-50 \% slopes, parent material: gravelly slope alluvium derived from schist, granite, and gneiss (Archrock); colluvium and till derived from granite, gneiss, and schist (Fallriver), 20 Kauwuneeche-Dystrocryepts complex, 1-15\% slopes, parent material: alluvium over sandy and gravelly glaciofluvial deposits derived from granite, gneiss, and schist (Kauwuneeche); alluvium derived from granite, schist, and gneiss (Dystrocryepts), 24 mummy extremely cobbly sandy loam, 20-50\%

one image every $5 \mathrm{~min}$ and simultaneously record date and time. We serviced cameras and recovered stored digital images semimonthly.

The numbers of animals/image (by species) present within licks were recorded and to avoid over counting animals within sequential images (i.e., likely the same group of animals), we utilized only the single image/ series containing the maximum number of individuals (count). We standardized our counts by calculating a species-specific daily visitation index (DVI; count/ day) for each camera in each period (PD), where $\mathrm{DVI}=24 \times\left(\sum_{j=1}^{D} \sum_{i=1}^{S} C_{i, j}\right) / \sum_{i=1}^{D} H_{j}, C_{i, j}$ count for the $i$ th sequence of photographs on the $j$ th day, $H_{j}$

slopes, parent material: colluvium and till derived from granite, gneiss, and schist, 42 Trailridge-Archrock complex, 10-40\% slopes, parent material: gravelly slope alluvium and residuum weathered from granite, gneiss, and schist (Trailridge); Gravelly slope alluvium derived from schist, granite, and gneiss (Archrock)] (on left) and satellite image (on right), where soil sample analyses and motion-activated cameras were used to assess Rocky Mountain elk (C. elaphus) and mule deer (O. virginianus) motivation for visitation to mineral licks in Rocky Mountain National Park, Colorado, June-September 2006

number of hours cameras were functional/day, $S=$ total number of photograph sequences/day, and $D$ total number of days with $\geq 12$ h of camera function. Days with $<12$ h of camera function were not used in calculating DVIs due to the potential for bias within these diurnal periods.

We also calculated a standardized soil consumption index (based on animals with their naso-oral region apparently in contact with soil; SCI) using the same equation as DVI, except $C_{i, j}=$ count of animals likely consuming soil. To calculate SCI, we used all images, including sequential images, because our objective was to index relative proportion of time spent in naso- 
oral contact with soil and potentially consuming soil, regardless of numbers of individuals represented.

We collected soil samples from within licks and nearby reference sites semimonthly in 50-ml conical plastic tubes from the top $5 \mathrm{~cm}$ of ground substrate. Sample-collection sites were arbitrarily selected within each lick ( $\geq 0.5 \mathrm{~m}$ from edge) and from adjacent reference sites (approximately $50 \mathrm{~m}$ north of where lick collections were taken). We stored samples at $0{ }^{\circ} \mathrm{C}$ until all sampling was complete, and then soil samples were dried at $50{ }^{\circ} \mathrm{C}$ for 1 week under a ventilation hood to remove moisture. Each sample was then mechanically homogenized with mortar and pestle and sieved $(2 \mathrm{~mm})$ to remove rock and debris. Equal amounts of soil from each sample location were sub-sampled and combined to generate a 20 -g composite sample for mineral composition analysis.

Colorado State University's Soils Laboratory analyzed bioavailable mineral concentrations $(\mathrm{mg} / \mathrm{kg})$ for our samples using inductively coupled plasma atomic emission spectroscopy on ammonium bicarbonatediethylenetriaminepentaacetic acid (AB-DTPA) extracts $(7.6 \mathrm{pH})$ for aluminum $(\mathrm{Al})$, boron $(\mathrm{B})$, barium $(\mathrm{Ba})$, cadmium $(\mathrm{Cd})$, chromium $(\mathrm{Cr})$, copper $(\mathrm{Cu})$, iron $(\mathrm{Fe})$, lead $(\mathrm{Pb}), \mathrm{Mg}$, manganese $(\mathrm{Mn})$, molybdenum (Mo), nickel (Ni), $\mathrm{P}$, potassium (K), Na, strontium (Sr), titanium (Ti), Vanadium (V), and zinc $(\mathrm{Zn})$, and ammonium acetate $\left(\mathrm{NH}_{4} \mathrm{OAc}\right)$ extracts for Ca (van Raij 1998; Imrie et al. 2009; Stephenson et al. 2011). We eliminated $\mathrm{B}, \mathrm{Ba}, \mathrm{Sr}$, and $\mathrm{Ti}$ from our analyses due to insufficient data on ruminant requirements, but retained $\mathrm{Al}$ and $\mathrm{Pb}$ due to potentially toxic effects (National Research Council 2007). When concentrations were below detection limits, we set concentration levels at one-half the detection limit and eliminated minerals from statistical analyses if more than half of sites were below revised detection limits (Ayotte et al. 2006).

We evaluated simple general linear models relating DVI and SCI (response variables) to explanatory variables including concentrations of each mineral $(\mathrm{mg} / \mathrm{kg})$ at licks, along with categorical variables: elevation class (EC: high or low), moisture class (MC: wet or dry), and period (PD: 1 or 2). We considered the following models with categorical predictor variables, only: ECIMCIPD, EC + MC + PD, ECIMC, EC + $\mathrm{MC}, \mathrm{ECIPD}, \mathrm{EC}+\mathrm{PD}, \mathrm{MCIPD}, \mathrm{MC}+\mathrm{PD}, \mathrm{EC}, \mathrm{MC}$, and $\mathrm{PD}$, where "I" indicates all fixed effects and interactions included in models, and " + " indicates main effects, only. We also considered models that included PD paired with each mineral concentration, with and without interaction, and models with each mineral concentration only. We excluded pairing of $\mathrm{MC}$ or EC with mineral concentrations because ranges of mineral concentrations between levels within MC and EC differed substantially, potentially leading to spurious modeling results. We ranked models by $\mathrm{AIC}_{\mathrm{C}}$ (Burnham and Anderson 2002) using the MIXED procedure of SAS with the maximum likelihood method. Subsequently, we reevaluated weight of evidence (Akaike weights, $w_{i}$; Burnham and Anderson 2002) for a reduced model set consisting of 14 models/ response variable including the highest-ranked model among combinations of categorical variables and the highest-ranked model for each mineral. We used restricted maximum likelihood for final model fitting of highly ranked models to optimize variance estimation (Littell et al. 2006). Analyses were viewed as exploratory; thus, we presented results from models with relatively low $w_{i}$ but with significant $(\alpha \leq 0.05)$ interaction terms or, for models without interactions, main-effects terms. We reported least squares means, standard errors (SE), $95 \%$ confidence intervals $(95 \%$ $\mathrm{CI}$ ), and degrees of freedom ( $d f$ ) for DVI or SCI and differences between means $(\Delta)$ for the highest-ranked categorical-only model. For models containing mineral concentrations, we reported estimates of slopes $(\beta)$ with SE, $95 \% \mathrm{CI}$, and $d f$ for each component of the highest-order term in the model.

\section{Results}

We monitored licks when they were completely free of snow beginning 1 June through 2 October. From June 29 to September 16, 2006, we collected imagery of visitation to licks by elk, deer, and occasionally moose. However, due to periodic battery failure, we only captured complete coverage during two distinct periods: 29 June to 27 July (period 1) and 23 August to 16 September (period 2). A total of 12,143 h of lick camera monitoring was accumulated and 1,563 elk and 329 deer were photographed. Although our photographic data revealed elk alongside deer within the same lick on three occasions (Fig. 2), such findings were relatively rare. Antlered animals totaled $82.6 \%$ of elk and $19.3 \%$ of deer counted at licks. Juvenile elk and deer comprised 3.7 and $3.9 \%$ of counts, 

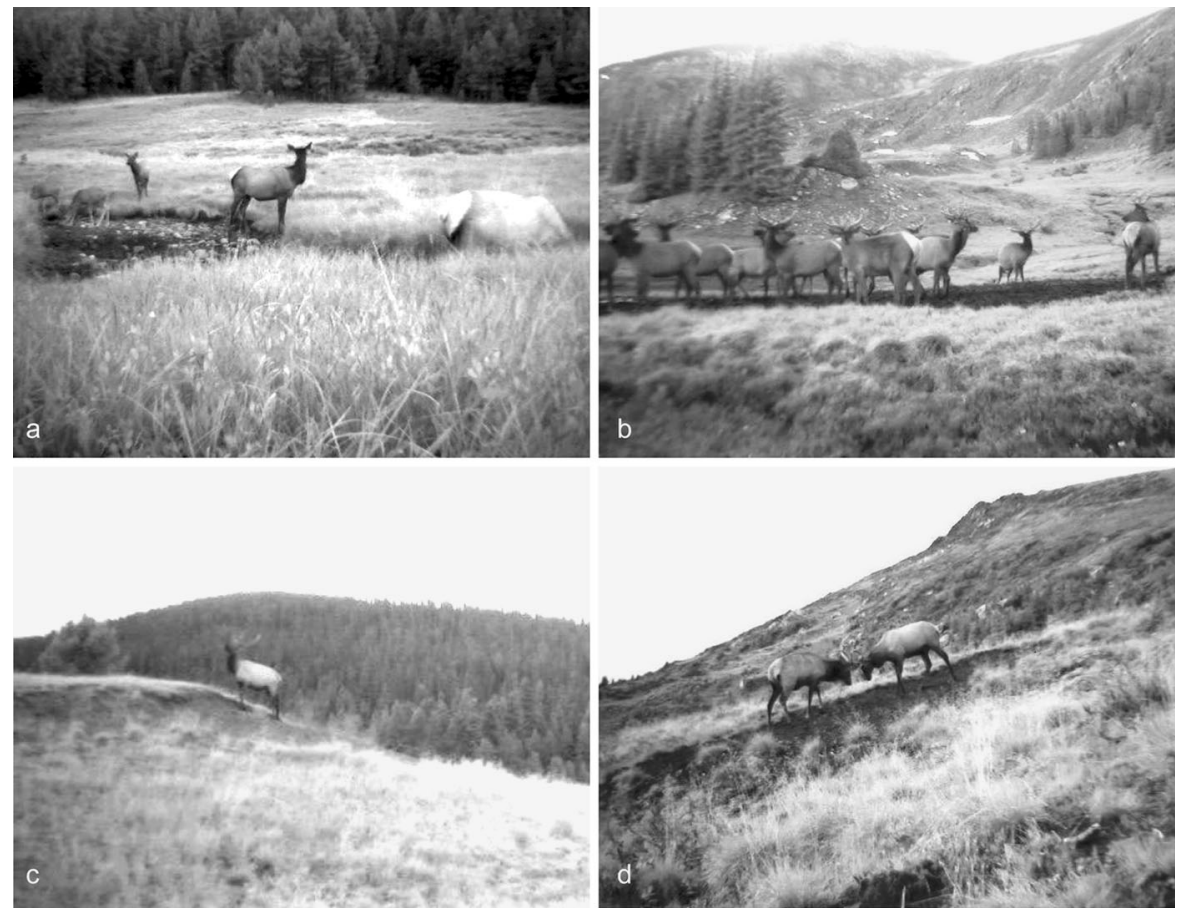

Fig. 2 Examples of data images depicting Rocky Mountain elk (C. elaphus) and mule deer (O. virginianus) activity at mineral licks in Rocky Mountain National Park, Colorado, JuneSeptember 2006. a Deer and elk head down and apparently

respectively, and all three visitations by moose involved antlerless animals. On average, we recorded 1.6 elk or 1.1 deer/image concurrently visiting licks. We also noted that $28 \%$ of elk and $70 \%$ of deer appeared to be consuming soil (naso-oral region in contact with lick contents; Fig. 2). We observed recumbent elk in licks in $14 \%$ of images, though we were unable to discriminate wallowing behavior versus resting animals from our single-photo data collection regime.

We classified five licks as dry and six as wet, and four licks as low elevation (valley floor, 3,026-3,123) and seven as high elevation (at or above timberline, 3,415-3,524 $\mathrm{m}$ ), resulting in cross-classification groups of three high-dry (D, J, K), four high-wet (A, B, C, E), two low-dry (H, I), and two low-wet (F, G) licks (Fig. 1; “Appendix"). Elk were present and appeared to consume soil at each lick during $\geq 1$ season (Fig. 3). The highest-ranked model relating elk DVI to explanatory variables (DVI $=$ PDIMn model; Table 1) included terms for intercept, period, Mn concentration, and period $\times \mathrm{Mn}$ interaction. This model described a positive trend in DVI with consuming soil in a low-elevation, wet mineral lick, b elk head up in a high-elevation wet mineral lick, $\mathbf{c}$ elk head up in a lowelevation, dry mineral lick, and $\mathbf{d}$ elk sparring and head up in a high-elevation, dry mineral lick

increasing Mn among licks in period 2 and a slightly decreasing, but statistically nonsignificant, trend in period 1 (Fig. 4; Table 2). We also found evidence of a positive relationship between DVI and Na concentration among licks in period two and a nonsignificant decreasing trend in period one (DVI = PDINa model; Fig. 4; Table 2). The third-ranked model (ECIPD; $w_{i}=0.013, k=5$ ) indicated elk were present at lowelevation licks in period two $\left(\mathrm{DVI}_{\mathrm{L}_{2}}=3.34\right.$ count/ day, $\mathrm{SE}=0.68,95 \%$ CI $1.90-4.77, d f=18)$ more frequently than in period one $\left(\Delta_{\mathrm{L}_{2}-\mathrm{L}_{1}}=3.06\right.$ count/ day, $\mathrm{SE}=0.97,95 \% \mathrm{CI} 0.33-5.79, d f=18)$ and more frequently than at high-elevation licks in period two $\left(\Delta_{\mathrm{L}_{2}-\mathrm{H}_{2}}=2.65, \mathrm{SE}=0.86,95 \%\right.$ CI 0.24-5.07; $d f=18$ ). Differences between other period $\times \mathrm{EC}$ combinations were not different from zero. Lower ranked models consisted of mineral concentration without period or period $\times$ mineral concentration and none indicated a relationship with DVI.

For the elk SCI response variable, the highestranked model was again PDIMn followed by the PDINa model (Table 1). We found positive trends in elk SCI with increasing $\mathrm{Mn}$ and $\mathrm{Na}$ in period two but 


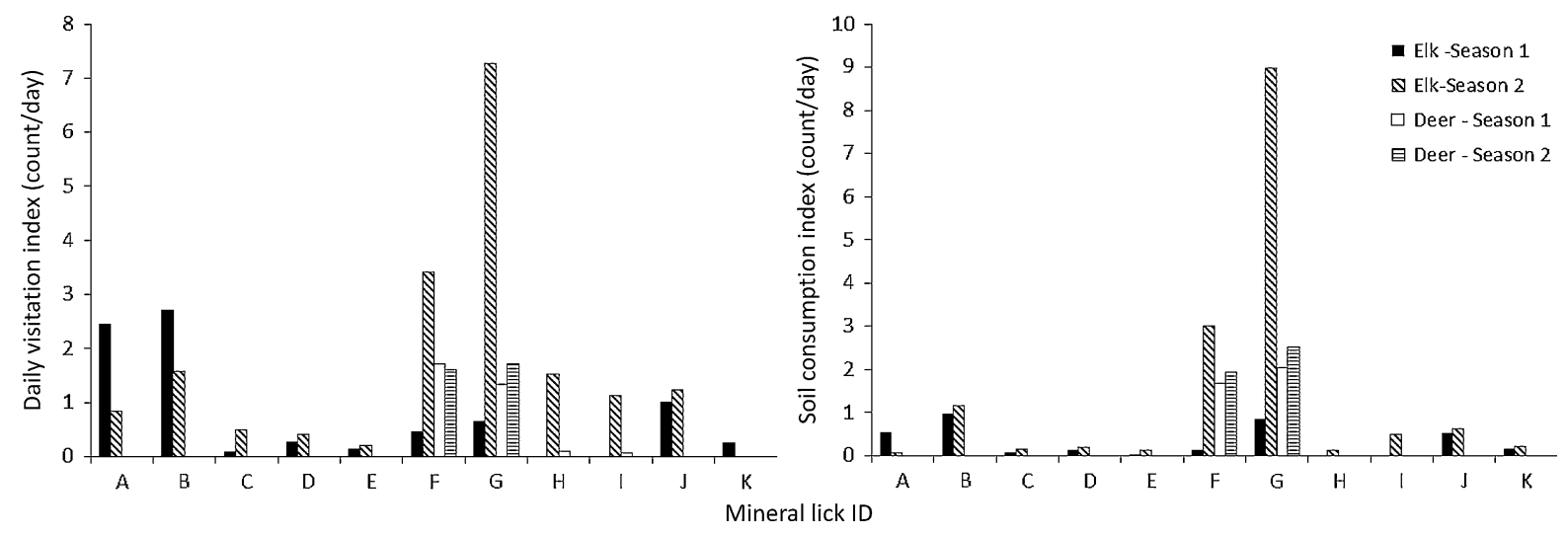

Fig. 3 Indices of daily visitation and probable soil consumption by Rocky Mountain elk (C. elaphus) and mule deer ( $O$. virginianus) at mineral licks in Rocky Mountain National Park, Colorado, June-September 2006. Mineral licks $F-I$ were low- elevation $(<3,200 \mathrm{~m})$ licks and the others were high elevation $(\geq 3,200 \mathrm{~m})$. Period 1 occurred June 29-July 27, 2006 and period 2 occurred August 23-September 16, 2006

Table 1 Highest-ranked models relating daily visitation indices (DVI) and soil consumption indices (SCI) of Rocky Mountain elk (C. elaphus) to explanatory variables for 11 mineral licks in Rocky Mountain National Park, Colorado, June-September 2006

\begin{tabular}{|c|c|c|c|c|c|c|c|}
\hline Response variable & Model $^{\mathrm{a}}$ & No. parameters & Log likelihood $^{\mathrm{b}}$ & $\mathrm{AIC}^{\mathrm{c}}$ & $\mathrm{AIC}_{\mathrm{C}}^{\mathrm{d}}$ & $\Delta \mathrm{AIC}_{\mathrm{C}}^{\mathrm{e}}$ & $w_{i}^{\mathrm{f}}$ \\
\hline \multirow[t]{3}{*}{ DVI } & PeriodIMn & 5 & -31.61 & 73.21 & 76.96 & 0.00 & 0.820 \\
\hline & PeriodINa & 5 & -34.30 & 78.60 & 82.35 & 5.39 & 0.055 \\
\hline & Period|EC & 5 & -35.86 & 81.72 & 85.47 & 8.51 & 0.012 \\
\hline \multirow[t]{2}{*}{ SCI } & PeriodIMn & 5 & -32.84 & 75.69 & 79.43 & 0.00 & 0.945 \\
\hline & PeriodINa & 5 & -37.41 & 84.83 & 88.58 & 9.14 & 0.010 \\
\hline
\end{tabular}

Models ranked using information-theoretic methods (Burnham and Anderson 2002)

a Vertical bar indicates models consisted of main effects and interaction

b Natural logarithm of the maximum likelihood estimate (i.e., maximum point of likelihood function generated in analysis)

c Akaike's information criterion: a function of log likelihood and number of parameters in a model

d Akaike's information criterion adjusted for small sample size

e Difference in $\mathrm{AIC}_{\mathrm{C}}$ between a model and the lowest $\mathrm{AIC}_{\mathrm{C}}$ model

f Akaike weights: relative weight of evidence in favor of model $i$ being the "best" model among those contained in a set of candidate models

no trend in period one for either mineral (Fig. 5; Table 2). The full categorical model was ranked third (ECIMCIPD), indicating elk SCI was greater for lowelevation, wet licks ( $\mathrm{F}$ and G; Fig. 3; Table 1) in period two $\left(\mathrm{SCI}_{\mathrm{WL}_{2}}=6.00\right.$ count/day, $\mathrm{SE}=0.84$, $95 \%$ CI 4.19-7.80, $d f=14)$ than for all seven other $\mathrm{EC} \times \mathrm{MC} \times \mathrm{PD}$ combinations (contrast differences between $\mathrm{SCI}_{\mathrm{WL}_{2}}$ and other $\mathrm{EC} \times \mathrm{MC} \times \mathrm{PD}$ combinations ranged 5.50-6.00 count/day).

We recorded deer at only four licks (the four lowelevation licks, primarily F and G; Fig. 3) and deer appeared to consume soil at only two of those licks ( $F$ and G). Consequently, we were unable to fit models of
DVI and SCI as functions of predictor variables for deer.

\section{Discussion}

Concentration of available minerals appeared to be the driving force motivating visitation to mineral licks by cervids in RMNP during our study. These concentrations were highly variable among licks though factors such as underlying bedrock, moisture class (regime), and location of licks explain much of this variation (Fig. 1). The pedogenic processes occurring at each of 
Fig. 4 Rocky Mountain elk (Cervus elaphus) daily visitation index (daily count of elk in photographs taken at 15 -min intervals) at mineral licks related to lick soil concentrations of manganese and sodium during periods 1 (June 29July 27, 2006, a, b) and 2 (August 23-September 16, 2006, c, d). Capital letters are used as symbols to match individual licks to observed data points and simple linear models are indicated by lines. Slopes of period-1 models were not different from zero $(\mathbf{a}, \mathbf{b})$

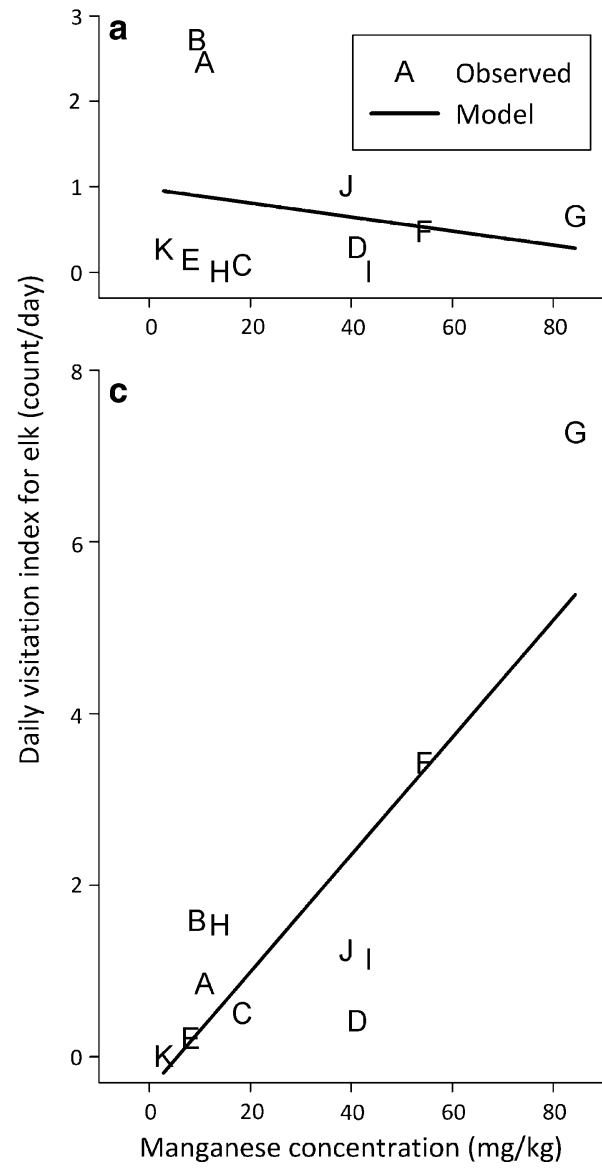

Table 2 Slopes $(\beta)$ of model-fitted relationships between two response variables DVI and SCI and independent variables PD, Mn, and Na for 11 mineral licks in Rocky Mountain National Park, Colorado, June-September 2006

\begin{tabular}{|c|c|c|c|c|c|c|c|}
\hline \multirow[t]{2}{*}{ Response variable } & \multirow[t]{2}{*}{ Model $^{\mathrm{a}}$} & \multirow[t]{2}{*}{ Period } & \multirow[t]{2}{*}{$\beta$} & \multirow[t]{2}{*}{$\mathrm{SE}^{\mathrm{b}}$} & \multicolumn{2}{|l|}{$95 \% \mathrm{CI}^{\mathrm{c}}$} & \multirow[t]{2}{*}{$d f^{\mathrm{d}}$} \\
\hline & & & & & Lower & Upper & \\
\hline \multirow[t]{4}{*}{ DVI } & \multirow[t]{2}{*}{ PDIMn } & 1 & -0.00819 & 0.0141 & -0.0379 & 0.0215 & 18 \\
\hline & & 2 & 0.0683 & 0.0141 & 0.0386 & 0.0980 & 18 \\
\hline & \multirow[t]{2}{*}{$\mathrm{PDINa}$} & 1 & -0.00258 & 0.00345 & -0.00982 & 0.00467 & 18 \\
\hline & & 2 & 0.0129 & 0.00345 & 0.00569 & 0.0202 & 18 \\
\hline \multirow[t]{4}{*}{ SCI } & \multirow[t]{2}{*}{ PDIMn } & 1 & 0.00327 & 0.0150 & -0.0282 & 0.0347 & 18 \\
\hline & & 2 & 0.0860 & 0.0150 & 0.0546 & 0.118 & 18 \\
\hline & \multirow[t]{2}{*}{$\mathrm{PDINa}$} & 1 & $<0.00001$ & 0.00397 & -0.00833 & 0.00835 & 18 \\
\hline & & 2 & 0.0158 & 0.00397 & 0.00774 & 0.0241 & 18 \\
\hline
\end{tabular}

$D V I$ daily visitation index (daily count of elk in photographs taken at 15-min intervals) and SCI: soil consumption index (daily count of elk exhibiting muzzle-to-ground posture in photographs taken at 15-min intervals), PD period 1 (June 29-July 27, 2006) and period 2 (August 23-September 16, 2006); mineral lick soil concentrations (mg/kg) of manganese (Mn) and sodium (Na)

a Vertical bar indicates models consisted of main effects and interaction

b $S E$ standard error of estimated slope

c $95 \%$ CI Confidence interval on estimated slope, where exclusion of 0 from interval implies statistical significance at the 0.05 level

d $d f$ Degrees of freedom of model 
Fig. 5 Rocky Mountain elk (C. elaphus) soil consumption index (daily count of elk exhibiting muzzle-to-ground posture in photographs taken at 15-min intervals) at mineral licks related to lick soil concentrations of manganese and sodium during periods 1 (June 29July 27, 2006, a, b) and 2 (August 23-September 16, 2006, c, d). Capital letters are used as symbols to match individual licks to observed data points and simple linear models are indicated by lines. Slopes of period-1 models were not different from zero $(\mathbf{a}, \mathbf{b})$

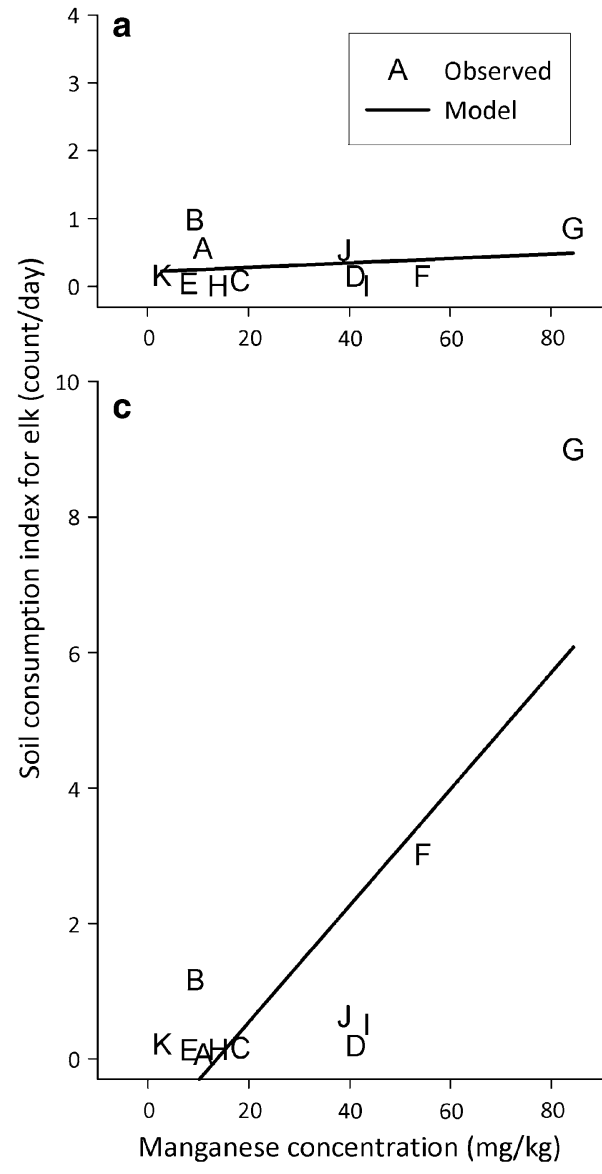

these landscape positions and under differing moisture regimes was the primary reason for the variable mineral concentrations found in our soil samples. The significance of this variation is due to the fact that the licks occurred along a topo-hydro sequence where the high-elevation licks were of the drier udic moisture regime and the low-elevation licks were of an acquic moisture regime in some portion of the soil profile (Natural Resources Conservation Service 1999). For example, high-elevation licks $\mathrm{E}, \mathrm{J}$, and $\mathrm{C}$ were in the Archrock (Loamy-skeletal, micaceous Typic Humicryepts), Trailridge (Loamy-skeletal, micaceous, shallow Humicryepts), and Fall River soil series (Natural Resources Conservation Service 2010). These are soils forming in alluvium (loose unconsolidated soil or sediment) over residuum from underlying granitic rocks, gneiss and schist. These are shallow soils, on fairly steep slopes with an udic moisture regime. The particle size distribution is dominated by rock fragments and sand with generally $<20 \%$ clay content, which is dominated by mica. They are acidic soils with $\mathrm{pHs}$ across the depth of the profile ranging from 5.0 to 4.8. Cation exchange capacities reported for these soils is on the order of $3 \mathrm{cmol}(+) / \mathrm{kg}$, and have low base saturation values (National Cooperative Soil Survey 2013).

Located on the shoulder position in the landscape, high-elevation licks A, B, D, and K, occurred within the Mummy series (Loamy-skeletal, micaceous Typic Humicryepts; Natural Resources Conservation Service 2010). These soils form in colluvium and till on moderately steep slopes with an udic moisture regime and have a thick high organic matter containing surface layer overlaying sandy loam textured soils dominated by rock fragments and sand, with $<20 \%$ clay. The Mummy series soils are acidic with reported $\mathrm{pHs}$ increasing from the surface at $\mathrm{pH} 4.8-5.4$ in the lower horizons. The CEC for this series ranges from $8.5 \mathrm{cmol}(+) / \mathrm{kg}$ at $12 \mathrm{~cm}$ below the surface to 2.2 $\mathrm{cmol}(+) / \mathrm{kg}$ at $40 \mathrm{~cm}$ depth with base saturations 
ranging from 40 to $60 \%$ (National Cooperative Soil Survey 2013). Decomposition in these soils is slow due to the low temperatures at these elevations and accumulations of humic material in the upper horizons. These soils drain rapidly due to the slope on the landscape and flush base ions, which are those apparently preferred minerals in our study $(\mathrm{Na}, \mathrm{K}$, $\mathrm{Ca}, \mathrm{Mg}, \mathrm{Mn}$ ), to lower positions in the landscape (i.e., our low-elevation sites).

Continuing downslope to the toe slope position in the landscape, the remaining licks $(\mathrm{F}, \mathrm{G}, \mathrm{H}$, and $\mathrm{I})$ are in the Kawuneeche series (Coarse-loamy, mixed, superactive, nonacid Fluvaquentic Cryaquepts; Natural Resources Conservation Service 2010). These soils form in alluvium derived from granite, gneiss and schist, often lying in flood plains along river valleys. The Kawuneeche series soils are nonacidic, with a $\mathrm{pH}$ near 5.2 at the surface, increasing to a $\mathrm{pH}$ of 6.4 with depth. The CEC for the Kawuneeche series is reported to range from $12.1 \mathrm{cmol}(+) / \mathrm{kg}$ in the surface horizons to $8.8 \mathrm{cmol}(+) / \mathrm{kg}$ in the lower horizons. Base saturation ranges from 40 to $70 \%$ (National Cooperative Soil Survey 2013). These soils receive materials from up slope either through erosional or water percolation processes. The elevated $\mathrm{pH}$ in these soils results in reduced $\mathrm{Al}$ and $\mathrm{Fe}$ concentrations as these metals precipitate out as oxyhydroxides (Hsu 1989; Schwertmann and Taylor 1989). The continuing percolation of water from upslope also brings base cations into the soil, increasing the concentrations of $\mathrm{Na}$ and $\mathrm{Ca}$. These additional processes are reflected in concentrations of minerals reported in "Appendix".

Our indices of elk and deer visitation and potential soil consumption at licks were positively related to concentrations of Mn and Na. For elk, these relationships were evident only in period two. Further, our $\mathrm{DVI}=\mathrm{ECIPD}$ model indicated that elk were most frequently observed at low-elevation licks in period two and our SCI = ECIMCIPD model indicated elk more frequently exhibited posture suggesting soil consumption at low-elevation wet licks (licks F and G) in period two (Fig. 3). This periodic difference contrasts markedly with deer observed in our study. Deer almost exclusively used low-elevation wet licks $\mathrm{F}$ and $\mathrm{G}$, but approximately equally during both periods. These licks exhibited the highest concentrations of $\mathrm{Mn}$ and $\mathrm{Na}$, were associated with the highest DVI and SCI rates for both deer and elk, and were the primary reason for positive relationships with $\mathrm{Mn}$ and
$\mathrm{Na}$ for elk. Both deer and elk appear to avoid lowelevation licks in the same soil series as there are elevated levels of potentially toxic Al present (licks F and $\mathrm{G}$ contrasted with $\mathrm{H}$ and $\mathrm{I}$ ).

Both $\mathrm{Mn}$ and $\mathrm{Na}$ are essential minerals for animals (National Research Council 2007). Assuming elk and deer select and visit licks primarily to ingest minerals (Klaus and Schmid 1998), they were possibly seeking $\mathrm{Mn}$ and/or $\mathrm{Na}$, which were at higher concentrations at licks $\mathrm{F}$ and $\mathrm{G}$ than other licks. Our study design (observational) and lack of contemporaneous estimates of mineral concentrations in cervid forages preclude cause-and-effect inference based on relationships we observed. However, we suggest that elk and deer were attracted to high-use licks by elevated $\mathrm{Na}$ concentrations and that relationships between $\mathrm{Mn}$ concentration and visitation were coincidental. Our reasoning includes: (1) most inland environments are deficient in $\mathrm{Na}$ (Kincaid 1988), animals can detect $\mathrm{Na}$ by taste (Schulkin 2001), and they will seek supplementation of $\mathrm{Na}$ when deficient in forage (Provenza and Villalba 2006) and (2) Mn deficiencies have not been documented in grazing animals (National Research Council 2007). Additionally, literature does not support the theory that animals can detect or will seek Mn supplementation, although consumption of $\mathrm{Mn}$-rich materials could be learned during periods of deficiency (Provenza and Villalba 2006). Dietary imbalances of metals (e.g., $\mathrm{Cu}, \mathrm{Mn}, \mathrm{Zn}$ ) have been associated with and may contribute to transmissible spongiform diseases such as CWD (Leach et al. 2007; Imrie et al. 2009; White et al. 2010; Wolfe et al. 2010). Further, the presence of $\mathrm{Mn}$ has been shown to increase both persistence of prions in soil (also $\mathrm{Cu}$ to a lesser extent) and infectivity of prions in cultured cells (Davies and Brown 2009). If abnormally high intake of $\mathrm{Mn}$ is incidental to focal intake of $\mathrm{Na}$, then risk of CWD transmission associated with lick use may be amplified.

Although beneficial in meeting mineral requirements, use of licks results in the congregation of animals increasing the likelihood of deposition and ingestion pathogens (Henshaw and Ayeni 1971; Miller et al. 2004; Schramm et al. 2006). Further, behaviors exhibited therein including defecation, urination, ejaculation, soil consumption, inhalation, drinking, and wallowing and bedding followed by grooming increase potential for transmission of pathogens (e.g., DeJoia et al. 2006; Jones and Hanson 1985; Nichols 
et al. 2013; Pedersen et al. 2006; Schramm et al. 2006; VerCauteren et al. 2007). Chronic wasting disease can be shed in urine, feces, and saliva (Haley et al. 2009; Tamgüney et al. 2009; Mathiason et al. 2006) and has a relatively high prevalence rate, up to $24 \%$, in RMNP (Pulford et al. 2012). Ingestion and inhalation of prions have also proven effective in transmission of CWD (Sigurdson et al. 1999; Nichols et al. 2013).

Geochemical characteristics of licks, behaviors that take place at licks, and nature of prions in soils merge to create a plausible scenario in which licks may act as reservoirs for maintaining disease (Johnson et al. 2006; Schramm et al. 2006; Davies and Brown 2009). Although it would be of obvious interest to determine the presence or absence of CWD at licks in this study, current technology limitations prevented us addressing this issue. Because of the complex matrices of soils, efforts to utilize protein misfolding cyclic amplification (PMCA), an ultrasensitive assay used to detect minute amounts of prions in tissues, have thus far been unsuccessful. Hopefully, the optimization of the PMCA assay in the future will allow such investigations.

In conclusion, we found that elk and deer at our study site most often visited and consumed soil at lowelevation wet licks high in Mn and Na. Although these results were primarily driven by only 2 of 11 lick sites, they are consistent with a body of knowledge showing that many mammals, including cervids, seek seasonal Na supplementation. We hypothesize that (1) presence of abundant $\mathrm{Na}$ is likely the key factor in lick selection we observed, (2) consumption of soil at licks high in $\mathrm{Na}$ may result in coincidental ingestion of relatively high and potentially harmful levels of Mn by cervids, and (3) visitation to and ingestion of potentially contaminated soils at licks may increase risk of CWD transmission. Expanded observational studies monitoring levels of cervid presence and use, along with replicated (within site) soil sampling and analysis, in conjunction with experimental studies to evaluate CWD transmission risk associated with elevated $\mathrm{Mn}$ concentration, are required to further investigate these hypotheses.

Acknowledgments We thank Terry Terrell and Judy Visty of the United States (US), National Park Service for facilitating research and access to Rocky Mountain National Park. Reviews by T. Atwood and S. Leach strengthened the manuscript. All procedures were approved by the US Department of Agriculture (USDA)-Animal and Plant Health Inspection Service-Wildlife Services-National Wildlife Research Center's (NWRC) Institutional Animal Care and Use Committee (QA-1267). All funding was provided by the NWRC. Mention of companies or commercial products does not imply recommendation or endorsement by the USDA over others not mentioned. USDA neither guarantees nor warrants the standard of any product mentioned. Product names are mentioned solely to report factually on available data and to provide specific information. The authors declare that they have no conflict of interest.

\section{Appendix}

Variables (Var) associated with mineral licks, including mineral concentrations $(\mathrm{Al}-\mathrm{Zn}, \mathrm{mg} / \mathrm{kg}$ ) at licks (L) and reference sites (Ref), elevation of lick (E, m), elevation class (EC), moisture class (MC), daily visitation index (DVI), and soil consumption index (SCI) during study periods 1 (PD1) and 2 (PD2) for Rocky Mountain elk (C. elaphus) and mule deer ( $O$. virginianus) in Rocky Mountain National Park, Colorado, June-September 2006. Period 1 occurred June 29-July 27, 2006, and period 2 occurred August 23September 16, 2006.

\begin{tabular}{|c|c|c|c|c|c|c|c|c|c|c|c|c|}
\hline Site & Sample & $\mathrm{Al}$ & $\mathrm{Ca}$ & $\mathrm{Cd}$ & $\mathrm{Cu}$ & $\mathrm{Cr}$ & $\mathrm{Fe}$ & $\mathrm{K}$ & $\mathrm{Mg}$ & $\mathrm{Mn}$ & $\mathrm{Na}$ & $\mathrm{Ni}$ \\
\hline \multirow[t]{2}{*}{ A } & Lick & 244 & 881 & 0.255 & 49.2 & 0.584 & 1,046 & 189 & 52.3 & 11.0 & 199 & 1.72 \\
\hline & Ref & 125 & 867 & 0.008 & 5.85 & 0.589 & 828 & 233 & 112 & 78.4 & 246 & $<0.01$ \\
\hline \multirow[t]{2}{*}{ B } & Lick & 288 & 714 & 0.254 & 40.0 & 0.939 & 1,159 & 442 & 43.0 & 9.43 & 208 & 1.49 \\
\hline & Ref & 127 & 1,008 & 0.001 & 10.1 & 0.355 & 543 & 488 & 127 & 115 & 264 & $<0.01$ \\
\hline \multirow[t]{2}{*}{$\mathrm{C}$} & Lick & 229 & 935 & 0.257 & 47.1 & 0.375 & 1,437 & 193 & 91.7 & 18.4 & 382 & 1.35 \\
\hline & Ref & 61.5 & 2,130 & 0.340 & 5.86 & 0.171 & 419 & 249 & 231 & 36.4 & 260 & 0.17 \\
\hline \multirow[t]{2}{*}{$\mathrm{D}$} & Lick & 106 & 1,072 & 0.041 & 12.4 & 0.637 & 504 & 345 & 128 & 41.2 & 242 & 0.04 \\
\hline & Ref & 61.1 & 1,846 & 0.113 & 8.19 & 0.306 & 392 & 322 & 194 & 37.6 & 252 & 0.18 \\
\hline \multirow[t]{2}{*}{$\mathrm{E}$} & Lick & 55.3 & 1,001 & 0.108 & 18.3 & 0.299 & 578 & 110 & 155 & 8.23 & 186 & 0.86 \\
\hline & Ref & 83.7 & 1,419 & 0.231 & 9.37 & 0.152 & 514 & 353 & 150 & 23.8 & 276 & 0.04 \\
\hline
\end{tabular}




\begin{tabular}{|c|c|c|c|c|c|c|c|c|c|c|c|c|c|c|}
\hline Site & Sample & \multicolumn{2}{|l|}{$\mathrm{Al}$} & $\mathrm{Ca}$ & $\mathrm{Cd}$ & $\mathrm{Cu}$ & $\mathrm{Cr}$ & \multicolumn{2}{|c|}{$\mathrm{Fe}$} & $\mathrm{K}$ & $\mathrm{Mg}$ & $\mathrm{Mn}$ & $\mathrm{Na}$ & $\mathrm{Ni}$ \\
\hline \multirow[t]{2}{*}{$\mathrm{F}$} & Lick & \multicolumn{2}{|c|}{41.3} & 2,066 & 0.109 & 18.3 & 0.255 & \multicolumn{2}{|c|}{739} & 145 & 223 & 54.5 & 443 & $<0.01$ \\
\hline & Ref & \multicolumn{2}{|c|}{91.4} & 1,566 & 0.035 & 50.3 & 0.28 & \multicolumn{2}{|c|}{1,056} & 262 & 124 & 81.1 & 210 & 0.44 \\
\hline G & Lick & 41.1 & & & 0.003 & 13.1 & 0.180 & 57 & & 162 & 393 & 84.4 & 482 & 0.06 \\
\hline & Ref & 166 & & & 0.090 & 11.8 & 0.39 & 83 & & 245 & 139 & 39.1 & 269 & $<0.01$ \\
\hline $\mathrm{H}$ & Lick & 259 & & 10 & 0.038 & 11.0 & 0.245 & 22 & & 171 & 89.5 & 14.0 & 245 & 0.05 \\
\hline & Ref & 58.9 & & & 0.003 & 11.9 & 0.26 & 70 & & 283 & 183 & 97.9 & 164 & $<0.01$ \\
\hline I & Lick & 86.3 & & & 0.040 & 25.8 & 0.346 & & & 823 & 347 & 43.4 & 377 & 1.51 \\
\hline & Ref & 51.7 & & & 0.069 & 66.3 & 0.37 & & & 362 & 685 & 177 & 432 & 1.28 \\
\hline $\mathrm{J}$ & Lick & 105 & & 15 & 0.027 & 18.0 & 0.662 & 62 & & 202 & 97.0 & 39.0 & 178 & $<0.01$ \\
\hline & Ref & 65.0 & & & 0.107 & 24.1 & 0.23 & 51 & & 474 & 187 & 84.2 & 272 & 0.02 \\
\hline K & Lick & 6.29 & & & 0.066 & 13.9 & 0.042 & 90 & & 81.8 & 437 & 2.78 & 156 & 0.78 \\
\hline & Ref & 108 & & & 0.340 & 13.5 & 0.24 & 58 & & 244 & 122 & 46.5 & 274 & 0.04 \\
\hline Site & Sample & $\mathrm{P}$ & $\mathrm{Zn}$ & $\mathrm{E}$ & $\mathrm{EC}$ & $\mathrm{MC}$ & Daily vi & sitation & ndex & & Soil co & nsumptic & index & \\
\hline & & & & & & & $\begin{array}{l}\text { Elk } \\
\text { PD1 }\end{array}$ & $\begin{array}{l}\text { Elk } \\
\text { PD2 }\end{array}$ & $\begin{array}{l}\text { Deer } \\
\text { PD1 }\end{array}$ & $\begin{array}{l}\text { Deer } \\
\text { PD2 }\end{array}$ & $\begin{array}{l}\text { Elk } \\
\text { PD1 }\end{array}$ & $\begin{array}{l}\text { Elk } \\
\text { PD2 }\end{array}$ & $\begin{array}{l}\text { Deer } \\
\text { PD1 }\end{array}$ & $\begin{array}{l}\text { Deer } \\
\text { PD2 }\end{array}$ \\
\hline A & Lick & 6.30 & 5.64 & 3,476 & High & Wet & 2.448 & 0.846 & 0 & 0 & 0.552 & 0.053 & 0 & 0 \\
\hline & Ref & 12.0 & 3.07 & & & & & & & & & & & \\
\hline B & Lick & 6.30 & 4.40 & 3,478 & High & Wet & 2.709 & 1.582 & 0 & 0 & 0.973 & 1.16 & 0 & 0 \\
\hline & Ref & 10.2 & 3.07 & & & & & & & & & & & \\
\hline $\mathrm{C}$ & Lick & 7.20 & 9.50 & 3,415 & High & Wet & 0.076 & 0.502 & 0 & 0 & 0.076 & 0.151 & 0 & 0 \\
\hline & Ref & 12.0 & 19.5 & & & & & & & & & & & \\
\hline D & Lick & 6.30 & 3.24 & 3,480 & High & Dry & 0.28 & 0.412 & 0 & 0 & 0.14 & 0.183 & 0 & 0 \\
\hline & Ref & 12.0 & 7.85 & & & & & & & & & & & \\
\hline $\mathrm{E}$ & Lick & 8.40 & 4.68 & 3,492 & High & Wet & 0.138 & 0.204 & 0 & 0 & 0.034 & 0.122 & 0 & 0 \\
\hline & Ref & 9.30 & 10.6 & & & & & & & & & & & \\
\hline $\mathrm{F}$ & Lick & 7.50 & 2.22 & 3,123 & Low & Wet & 0.465 & 3.418 & 1.718 & 1.606 & 0.143 & 3.006 & 1.682 & 1.936 \\
\hline & Ref & 12.9 & 15.5 & & & & & & & & & & & \\
\hline G & Lick & 7.50 & 1.66 & 3,111 & Low & Wet & 0.646 & 7.27 & 1.342 & 1.72 & 0.845 & 8.99 & 2.038 & 2.502 \\
\hline & Ref & 12.0 & 4.07 & & & & & & & & & & & \\
\hline $\mathrm{H}$ & Lick & 12.0 & 1.60 & 3,093 & Low & Dry & 0 & 1.529 & 0.095 & 0 & 0 & 0.127 & 0 & 0 \\
\hline & Ref & 16.8 & 6.31 & & & & & & & & & & & \\
\hline I & Lick & 7.20 & 6.59 & 3,026 & Low & Dry & 0 & 1.133 & 0.074 & 0 & 0 & 0.496 & 0 & 0 \\
\hline & Ref & 24.8 & 29.3 & & & & & & & & & & & \\
\hline $\mathrm{J}$ & Lick & 7.50 & 1.28 & 3,524 & High & Dry & 1.004 & 1.234 & 0 & 0 & 0.521 & 0.617 & 0 & 0 \\
\hline & Ref & 8.4 & 14.8 & & & & & & & & & & & \\
\hline K & Lick & 7.50 & 4.77 & 3,522 & High & Dry & 0.261 & 0 & 0 & 0 & 0.149 & 0.207 & 0 & 0 \\
\hline & Ref & 10.1 & 18.9 & & & & & & & & & & & \\
\hline
\end{tabular}

\section{References}

Ayotte, J. B., Parker, K. L., Arocena, J. M., \& Gillingham, M. P. (2008). Use of natural licks by four species ungulates in northern British Columbia. Journal of Mammalogy, 89(4), 1041-1050.
Ayotte, J. B., Parker, K. L., \& Gillingham, M. P. (2006). Chemical composition of lick soils: Functions of soil ingestion by four ungulate species. Journal of Mammalogy, 87(5), 878-888.

Burnham, K. P., \& Anderson, D. R. (2002). Model selection and multimodel inference: A practical information-theoretic approach (2nd ed.). New York: Springer. 
Campbell, T. A., \& Hewitt, D. G. (2004). Mineral metabolism by white-tailed deer fed diets of guajillo. Southwestern Naturalist, 49(3), 367-375.

Case, G. W. (1938). The use of salt in controlling the distribution of game. Journal of Wildlife Management, 2(3), 79-81.

Colorado Division of Wildlife. (2010a). 2010 CWD prevalence for deer by DAU. Colorado Division of Wildlife. http://wild life.state.co.us/SiteCollectionDocuments/DOW/Hunting/ BigGame/CWD/PDF/TestResults/CWDDeer2010.pdf. Accessed April 25, 2012.

Colorado Division of Wildlife. (2010b). 2010 CWD prevalence for elk by DAU. Colorado Division of Wildlife. http:// wildlife.state.co.us/SiteCollectionDocuments/DOW/Hunt ing/BigGame/CWD/PDF/TestResults/CWDElk2010.pdf. Accessed April 25, 2012.

Davies, P., \& Brown, D. R. (2009). Manganese enhances prion protein survival in model soils and increases prion infectivity to cells. PLoS One, 4(10), e7518.

DeJoia, C., Moreaux, B., O’Connell, K., \& Bessen, R. A. (2006). Prion infection of oral and nasal mucosa. Journal of Virology, 80(9), 4546-4556.

Denton, D. A., Blair-West, J. R., McKinley, M. J., \& Nelson, J. F. (1986). Physiological analysis of bone appetite (osteophagia). BioEssays, 4(1), 40-42.

Fischer, J. W., \& Lavelle, M. J. (2007). Mineral licks: Evaluating their role in disease transmission. ArcNews Online, $30(1)$.

Haley, N. J., Mathiason, C. K., Zabel, M. D., Telling, B. C., \& Hoover, E. A. (2009). Detection of sub-clinical CWD infection in conventional test-negative deer long after oral exposure to urine and feces from CWD+ deer. PLoS One, 4(11), e7990.

Henshaw, J., \& Ayeni, J. (1971). Some aspects of big-game utilization of mineral licks in Yankari Game Preserve, Nigeria. East African Wildlife Journal, 9(1), 73-82.

Hsu, P. H. (1989). Aluminum oxides and oxyhydroxides. In J. B. Dixon \& S. B. Weed (Eds.), Minerals in soil environments (pp. 331-378). Madison, WI: Soil Science Society of America.

Imrie, C. E., Korre, A., \& Munoz-Melendez, G. (2009). Spatial correlation between the prevalence of transmissible spongiform diseases and British soil geochemistry. Environmental Geochemistry and Health, 31, 133-145.

Johnson, C. J., Phillips, K. E., Schramm, P. T., McKenzie, D., Aiken, J. M., \& Pedersen, J. A. (2006). Prions adhere to soil minerals and remain infectious. PLoS Pathogens, 2(4), e32.

Jones, R. L., \& Hanson, H. C. (1985). Mineral licks, geophagy, and biogeochemistry of North American ungulates. Ames: Iowa State University.

Jones, R. L., \& Weeks, H. P. (1985). Ca, Mg, and P in the annual diet of deer in south-central Indiana. Journal of Wildlife Management, 49(1), 129-133.

Kincaid, R. (1988). Macro elements for ruminants. In D. C. Church (Ed.), The ruminant animal: Digestive physiology and nutrition (pp. 326-341). NJ: Englewood Cliffs.

Klaus, G., \& Schmid, B. (1998). Geophagy at natural licks and mammal ecology: A review. Mammalia, 62(4), 481-497.

Larkins, K. F. (1997). Patterns of elk movement and distribution in and adjacent to the eastern boundary of Rocky Mountain National Park (p. 155). M.A. thesis, University of Northern Colorado, Greeley.
Leach, S. P., Salman, M. D., \& Hamar, D. (2007). Trace elements and prion diseases: A review of the interactions of copper, manganese and zinc with prion protein. Animal Health Research Reviews, 7(1/2), 97-105.

Littell, R. C., Milliken, G. A., Stroup, W. W., Wolfinger, R. D., $\&$ Schabenberger, O. (2006). SAS for mixed models (2nd ed.). Cary, NC: SAS Institute.

Mathiason, C. K., Powers, J. G., Dahmes, S. J., Osborn, D. A., Miller, K. V., Warren, R. J., et al. (2006). Infectious prions in the saliva and blood of deer with chronic wasting disease. Science, 314(5796), 133-136.

McCaughey, S. A., \& Tordoff, M. G. (2002). Magnesium appetite in the rat. Appetite, 38(1), 29-38.

Miller, M. W., Williams, E. S., Hobbs, N. T., \& Wolfe, L. L. (2004). Environmental sources of prion transmission in mule deer. Emerging Infectious Diseases, 10(6), 1003-1006.

National Cooperative Soil Survey. (2013). National cooperative soil characterization database. http://ncsslabdatamart.sc. egov.usda.gov. Accessed April 20, 2013.

National Research Council. (2007). Nutrient requirements of small ruminants: Sheep, goats, cervids, and new world camelids. Washington, DC: National Academies Press.

Natural Resources Conservation Service. (1999). Soil taxonomy: A basic system of soil classification for making and interpreting soil surveys (2nd ed.). US Department of Agriculture Handbook No. 436.

Natural Resources Conservation Service. (2010). United States Department of Agriculture. Official Soil Series Descriptions. http://soils.usda.gov/technical/classification/osd/index. html. Accessed April 20, 2013.

Nichols, T. A., Spraker, T. R., Rigg, T. D., Meyerett-Reid, C., Hoover, C., Michel, B., et al. (2013). Intranasal inoculation of white-tailed deer (Odocoileus virginianus) with lyophilized chronic wasting disease prion particulate complexed to montmorillonite clay. PLos One, 8(5), e62455.

Pedersen, J. A., McMahon, K. D., \& Benson, C. H. (2006). Prions: Novel pathogens of environmental concern. Journal of Environmental Engineering, 132(967), 967-969.

Provenza, F. D., \& Villalba, J. J. (2006). Foraging in domestic herbivores: Linking the internal and external milieux. In V. Bels (Ed.), Feeding in domestic vertebrates: From structure to behaviour. Wallingford, Oxfordshire: CABI Publishing.

Pulford, B., Spraker, T. R., Wyckoff, A. C., Meyerett, C., Bender, H., Ferguson, A., et al. (2012). Detection of PrPCWD in feces from naturally exposed Rocky Mountain elk (Cervus elaphus Nelsoni) using protein misfolding cyclic amplification. Journal of Wildlife Diseases, 48(2), $425-434$.

Schramm, P. T., Johnson, C. J., Mathews, N. E., McKenzie, D., Aiken, J. M., \& Pedersen, J. A. (2006). Potential role of soil in the transmission of prion disease. Reviews in Mineralogy and Geochemistry, 64(1), 135-152.

Schulkin, J. (2001). Calcium hunger: Behavioral and biological regulation. New York: Cambridge University.

Schultz, S. R., \& Johnson, M. K. (1992). Effects of supplemental mineral licks on white-tailed deer. Wildlife Society Bulletin, 20(3), 303-308.

Schwertmann, U., \& Taylor, R. M. (1989). Iron oxides. In J. B. Dixon \& S. B. Weed (Eds.), Minerals in soil 
environments (pp. 379-439). Madison, WI: Soil Science Society of America.

Sigurdson, C., Williams, E. S., Miller, M. W., Spraker, T. R., O'Rourke, K. I., \& Hoover, E. A. (1999). Oral transmission and early lymphoid tropism of chronic wasting disease in mule deer fawns (Odocoileus hemionus). Journal of General Virology, 80(10), 2757-2764.

Spraker, T. R., Miller, M. W., Williams, E. S., Getzy, D. M., Adrian, W. J., Schoonveld, G. G., et al. (1997). Spongiform encephalopathy in free-ranging mule deer (Odocoileus hemionus), white-tailed deer (Odocoileus virginianus), and Rocky Mountain Elk (Cervus elaphus nelsoni) in northcentral Colorado. Journal of Wildlife Diseases, 33(1), 1-6.

Stephenson, J. D., Mills, A., Eksteen, J. J., Milewski, A. V., \& Myburgh, J. G. (2011). Geochemistry of mineral licks at Loskop Dam Nature Reserve, Mpumalanga, South Africa. Environmental Geochemistry and Health, 33, 49-53.

Tamgüney, G., Miller, M. W., Wolfe, L. L., Sirochman, T. M., Glidden, D. V., Palmer, C., et al. (2009). Asymptomatic deer excrete infectious prions in faeces. Nature, 461, 529-533.
Tordoff, M. G. (2001). Calcium: Taste, intake, and appetite. Physiological Reviews, 81(4), 1567-1597.

van Raij, B. (1998). Bioavailable tests: Alternatives to standard soil extractions. Communications in Soil Science and Plant Analysis, 29(11-14), 1553-1570.

VerCauteren, K. C., Burke, P. W., Phillips, G. E., Fischer, J. W., Seward, N. W., Wunder, B. A., et al. (2007). Elk use of wallows: Implications for disease transmission. Journal of Wildlife Diseases, 43(4), 784-788.

White, S. N., O’Rourke, K. I., Gidlewski, T., VerCauteren, K. C., Mousel, M. R., Phillips, G. E., et al. (2010). Increased risk of chronic wasting disease in Rocky Mountain elk associated with decreased magnesium and increased manganese in brain tissue. Canadian Journal of Veterinary Research, 74(1), 50-53.

Wolfe, L. L., Conner, M. M., Bedwell, C. L., Lukacs, P. M., \& Miller, M. W. (2010). Select tissue mineral concentrations and chronic wasting disease status in mule deer from northcentral Colorado. Journal of Wildlife Diseases, 46(3), 1029-1034. 